\title{
Genetic Engineering in Conifer Plantation Forestry
}

\author{
By A. R. Henderson*) and C. Walter \\ Cellwall Biotechnology Centre, Scion (the trading name for New Zealand Forest Research Institute Ltd.) \\ Private Bag 3020, Sala Street, Rotorua, New Zealand \\ (Received: August 28, 2006/Accepted: October 25, 2006)
}

\begin{abstract}
In this review we examine the history and progression of conifer genetic engineering. The review includes the methods used, the conifer species transformed, the genes inserted and the regeneration of genetically engineered conifer trees. We cover both Biolistic ${ }^{\circledR}$ and Agrobacterium-mediated transformation, and we detail transformation events with and without plant regeneration. We show that almost all conifer transformation work uses $n p t \mathrm{II}$ as a selective marker, and very often uidA is included as a reporter gene. Further, we show that a range of genes that are of commercial interest for forest tree plantations have been introduced, such as herbicide resistance, insect resistance and those related to wood properties. We briefly discuss the future for biotechnology in the context of socially acceptable enhanced plantation forestry and under consideration of benefits and risks.
\end{abstract}

Key words: Genetic engineering, conifers, plantation forestry.

\section{Introduction}

Conifers have been very successful in establishing themselves in various ecological niches around the world. They are highly flexible with regard to their ability to grow in diverse and often harsh environmental conditions, which makes them suitable to play a major role in commercial forestry. Conifer forestry contributes to the economic and social well being of many countries, and the use of plantation forests has a significant positive impact on natural forests and world climate balance. The demand for forest products such as pulp, paper and timber is ever increasing (FAO, 2004; WALTER and FenNing, 2004). The wood for these products will have to come even more from highly managed plantations in the future. Above all, this is important if the world's population chooses to leave natural forests untouched.

Conifer genetic improvement through breeding began in the southern U.S. (Texas and North Carolina) in the early 1950 s, and was quickly followed by programs elsewhere in the U.S., as well as New Zealand, South Africa, South America and Australia (ZOBEL and TALBERT, 1984). Breeding has proven to be a very effective tool, and since the level of domestication of forest trees still is very low, breeding is expected to achieve substantially increased genetic gains in the future. Many programs report yield increases, in the order of $1 \%$ or more for each year of breeding, and with similar levels of gains in other traits (SEDJO, 2004; WHITE and CARSON, 2004).

\footnotetext{
*) Corresponding author: ANNA R. Henderson. E-mail: anna.

henderson@scionresearch.com
}

Conifer clonal forestry, as a form of plantation forestry, can be defined as afforestation with a restricted number of vegetatively-propagated clones, which have been tested and selected in clonal trials, the best being subsequently mass produced (MENZIES and AIMERSHALLIDAY, 2004). Although implementation has been slow with conifers, the potential benefits of clonal forestry for pines have often been cited (CARSON, 1986; LiBBy, 1982; LiBBY and RAUTER, 1984). Gains arise from testing and selection of clones, clone/site matching to increase genetic gains, greater uniformity and greater repeatability.

Clonal propagation programs in conifers have combined the use of tissue culture with further multiplication using rooted cuttings to provide a cost-effective route to forestry (HAINES and WALKER, 1996; LIBBY and Hood, 1976; Menzies, 1994; Menzies and Aimers-HalliDAY, 1997). Somatic embryogenesis (SE) can also be used as a propagation tool and it offers the added advantage of providing an in vitro storage method for clonal germplasm (MENZIES and AIMERS-HALlidaY, 2004; SMITH et al., 1994; SutTon et al., 2004). Furthermore, SE is often the tissue culture technique of choice for genetic transformation in particular when regeneration of transgenic trees is required (e.g. FIND et al., 2005; KLIMASZEWSKA et al., 1997; WALTER et al., 1998b, 1999).

At current rates of research and development progress, there can be little doubt that clonal forestry will become increasingly widespread in the near future in response to an increasing world demand for sustainably-managed wood and fibre products. This can be enhanced through the introduction of modern biotechnology methods, in particular genetic engineering, which is particularly fitting to clonal forestry applications.

\section{Conifer genetic engineering}

Genetic engineering has been used commercially for over a decade, to produce agricultural plants resistant to herbicides (MAZUR and FALCO, 1989), insects (SHARMA et al., 2004), adverse environmental conditions (WANG et al., 2003), and with improved nutritional or medicinal value (SAUTTER et al., 2006). These modern biotechnologies have contributed to gains in productivity and quality of agricultural crops (CARDOZA and STEWART, 2004) and farmers have taken up improved varieties at unprecedented speed. At present, almost 100 million hectares are planted with genetically modified agricultural species, mainly soybean, canola, cotton and maize (ISAAA, 2005). 
Table 1. - Research published on transformation of conifer tissue. No transgenic plants were produced. Abbreviations: aph: gene for amino glycoside phosphotransferase; Ar: Agrobacterium rhizogenes; At: Agrobacterium tumefaciens; Asp: Agrobacterium species; B: Biolistic ${ }^{\circledR}$; bar: gene for phosphinothrycin resistance; cad: cinnamyl alcohol dehydrogenase gene; cat: chloramphenicol acetyltransferase gene; E: Electroporaton; gfp: gene for green fluorescent protein; luc: gene for luciferase; $n p t \mathrm{II}$ : gene for neomycin phosphotransferase; P: PEG : Polyethylene Glycol mediated; Ti: tumor inducing; uidA: gene for $\beta$-glucuronidase.

\begin{tabular}{|c|c|c|c|}
\hline Species & $\begin{array}{l}\text { Transformation } \\
\text { method }\end{array}$ & Transferred gene/s & Reference \\
\hline Abies procera & Ar & Ti T-DNA & MORRIS et al., 1989 \\
\hline Abies procera & At & Ti T-DNA & MORRIS et al., 1989 \\
\hline $\begin{array}{l}\text { Chamaecyparis } \\
\text { nootkatensis }\end{array}$ & $\mathrm{B}$ & nptII, uidA & HAY et al., 1994 \\
\hline Cryptomeria japonica & $\mathrm{B}$ & luc & MOHRI et al., 2000 \\
\hline $\begin{array}{l}\text { Cupressus } \\
\text { sempervirens }\end{array}$ & $\mathrm{B}$ & $n p t \mathrm{II}$, uidA, $g f p$ & LAMBARDI et al., 1998 \\
\hline Larix decidua & A sp. & Ti T-DNA & HUANG et al., 1993 \\
\hline Larix decidua & Ar & Ti T-DNA & $\begin{array}{l}\text { DINER and KARNOSKY, } \\
1987\end{array}$ \\
\hline Larix decidua & $\mathrm{B}$ & nptII, uidA & DUCHESNE et al., 1993 \\
\hline Larix leptolepis & $\mathrm{B}$ & nptII, uidA & DUCHESNE et al., 1993 \\
\hline Larix $x$ eurolepis & $\mathrm{B}$ & $\begin{array}{l}\text { nptII, uidA } \\
n p t \mathrm{II}, \text { uidA } \\
\text { uidA }\end{array}$ & $\begin{array}{l}\text { CHAREST et al., 1993; } \\
\text { DUCHESNE et al., 1993; } \\
\text { DUCHESNE and } \\
\text { CHAREST, } 1992\end{array}$ \\
\hline Larix $x$ leptoeuropae & $\mathrm{B}$ & $n p t \mathrm{II}$, uidA & DUCHESNE et al., 1993 \\
\hline Pinus aristata & $\mathrm{B}$ & uidA & FERNANDO et al., 2000 \\
\hline P. banksiana & $\mathrm{B}$ & nptII, uidA & HAY et al., 1994 \\
\hline P. banksiana & $\mathrm{E}$ & cat & TAUTORUS et al., 1989 \\
\hline$P$. contorta & Ar & $\begin{array}{l}\text { Root inducing } \\
\text { plasmid or T-DNA } \\
\text { uidA }\end{array}$ & $\begin{array}{l}\text { MAGNUSSEN et al., 1994; } \\
\text { YIBRAH et al., } 1996\end{array}$ \\
\hline P. concorta & $B$ & nptII, uidA & HAY et al., 1994 \\
\hline P. densiflora & $\mathrm{B}$ & uidA, luc & MOHRI et al., 2000 \\
\hline P. echinata & At & Ti T-DNA & HUANG and TAUER, 1994 \\
\hline P. elliottii & At & Ti T-DNA & HUANG and TAUER, 1994 \\
\hline P. griffithii & $\mathrm{B}$ & uidA & FERNANDO et al., 2000 \\
\hline P. halepensis & $\mathrm{Ar}$ & nptII, uidA, T-DNA & TZFIRA et al., 1996 \\
\hline P. lambertiana & At & nptII, Ti T-DNA & LOOPSTRA et al., 1990 \\
\hline P. menziessii & $\mathrm{E}$ & luc & GUPTA et al., 1988 \\
\hline P. monticola & B & uidA & FERNANDO et al., 2000 \\
\hline P. nigra & Ar & T-DNA & MIHALJEVIC et al., 1996 \\
\hline P. nigra & At & T-DNA & MIHALJEVIC et al., 1996 \\
\hline P. nigra & $\mathrm{B}$ & $\begin{array}{l}\text { uidA } \\
\text { nptII, uidA }\end{array}$ & $\begin{array}{l}\text { HUMARA et al., 1998; } \\
\text { SALAJ et al., } 2005\end{array}$ \\
\hline P. patula & $\mathrm{B}$ & uidA, bar & NIGRO et al., 2004 \\
\hline P. pinea & At & uidA & HUMARA et al., 1999 \\
\hline P. pinea & $\mathrm{B}$ & uidA & HUMARA et al., 1998 \\
\hline P. ponderosa & Ar & T-DNA & MORRIS et al., 1989 \\
\hline P. ponderosa & At & Ti T-DNA & MORRIS et al., 1989 \\
\hline$P$. radiata & At & $\begin{array}{l}\text { nptII, uidA } \\
n p t \mathrm{II}, \text { uidA } \\
\text { uidA }\end{array}$ & $\begin{array}{l}\text { CERDA et al., 2002; } \\
\text { CHARITY et al., 2002; } \\
\text { HOLLAND et al., 1997 }\end{array}$ \\
\hline$P$. radiata & $\mathrm{B}$ & $\begin{array}{l}\text { uidA, luc } \\
\text { nptII, cad } \\
\text { nptII, uidA } \\
\text { nptII, uidA, cad } \\
\text { nptII, uidA }\end{array}$ & $\begin{array}{l}\text { CAMPBELL et al., 1992; } \\
\text { MÖLLER et al., 2003; } \\
\text { REY et al., 1996; } \\
\text { WAGNER et al., 1997; } \\
\text { WALTER et al., } 1994\end{array}$ \\
\hline P. radiata & $\mathrm{E}$ & uidA, luc & CAMPBELL et al., 1992 \\
\hline P. rubens & B & $n p t \mathrm{II}, u i d \mathrm{~A}$ & CHAREST et al., 1993 \\
\hline$P$. sitchensis & At & $\begin{array}{l}\text { uidA } \\
\text { nptII, Ti T-DNA, luc }\end{array}$ & $\begin{array}{l}\text { DRAKE et al., } 1997 ; \\
\text { ELLIS et al., } 1989\end{array}$ \\
\hline P. strobus & $\mathrm{B}$ & nptII, gfp & TIAN et al., 1999 \\
\hline P. sylvestris & Ar & $\begin{array}{l}\text { Root inducing } \\
\text { plasmid or T-DNA }\end{array}$ & MAGNUSSEN et al., 1994 \\
\hline P. sylvestris & $\mathrm{B}$ & $\begin{array}{l}\text { uidA } \\
\text { uidA } \\
\text { nptII, uidA } \\
\text { uidA }\end{array}$ & $\begin{array}{l}\text { ARONEN et al., 1995, } \\
\text { ARONEN et al., 1998; } \\
\text { HÄGGMAN and } \\
\text { ARONEN, 1998; } \\
\text { HÄGGMAN et al., } 1997\end{array}$ \\
\hline
\end{tabular}


Table 1. - Continued.

\begin{tabular}{|c|c|c|c|}
\hline Species & $\begin{array}{l}\text { Transformation } \\
\text { method }\end{array}$ & Transferred gene/s & Reference \\
\hline P. taeda & At & $\begin{array}{l}\text { Ti T-DNA } \\
\text { Ti T-DNA } \\
\text { uidA } \\
\text { nptII, hpt, uidA }\end{array}$ & $\begin{array}{l}\text { HUANG and TAUER, } \\
\text { 1994; } \\
\text { SEDEROFF et al., 1986; } \\
\text { TANG, 2001; } \\
\text { WENCK et al., } 1999\end{array}$ \\
\hline P. taeda & B & uidA & STOMP et al., 1991 \\
\hline P. taeda & E & luc & GUPTA et al., 1988 \\
\hline P. thunbergii & B & uidA, luc & MOHRI et al., 2000 \\
\hline Picea abies & Ar & $\begin{array}{l}\text { Root inducing } \\
\text { plasmid or T-DNA }\end{array}$ & MAGNUSSEN et al., 1994 \\
\hline Picea abies & At & $\begin{array}{l}\text { Ti T-DNA } \\
n p t \mathrm{II}, \text { uidA } \\
n p t \mathrm{II}, h p t, u i d \mathrm{~A}\end{array}$ & $\begin{array}{l}\text { CLAPHAM et al., 1990; } \\
\text { KLIMASZEWSKA et al., } \\
\text { 2003; } \\
\text { WENCK et al., } 1999\end{array}$ \\
\hline Picea abies & B & $\begin{array}{l}\text { uidA } \\
\text { uidA } \\
\text { Root inducing } \\
\text { plasmid or Ti T- } \\
\text { DNA } \\
\text { nptII, uidA }\end{array}$ & $\begin{array}{l}\text { ARONEN et al., 1998; } \\
\text { HÄGGMAN et al., 1997; } \\
\text { MARTINUSSEN et al., } \\
\text { 1994; } \\
\text { ROBERTSON et al., } 1992\end{array}$ \\
\hline Picea engelmanni & At & nptII, Ti T-DNA, luc & ELLIS et al., 1989 \\
\hline Picea glauca & At & $\begin{array}{l}n p t I I, \text { Ti T-DNA, luc } \\
\text { nptII, uidA }\end{array}$ & $\begin{array}{l}\text { ELLIS et al., 1989; } \\
\text { KLIMASZEWSKA et al., } \\
2003\end{array}$ \\
\hline Picea glauca & B & $\begin{array}{l}\text { nptII, uidA } \\
\text { uidA } \\
\text { uidA }\end{array}$ & $\begin{array}{l}\text { CHAREST et al., 1993; } \\
\text { ELLIS et al., 1991; } \\
\text { LI et al., 1994 }\end{array}$ \\
\hline Picea glauca & E & uidA, cat & BEKKAOUI et al., 1988 \\
\hline Picea glauca & PEG & uidA, cat & WILSON et al., 1989 \\
\hline Picea mariana & At & $n p t \mathrm{II}$, uidA & $\begin{array}{l}\text { KLIMASZEWSKA et al., } \\
2003\end{array}$ \\
\hline Picea mariana & B & $\begin{array}{l}n p t \mathrm{II}, \text { uidA } \\
n p t \mathrm{II}, \text { uidA } \\
n p t \mathrm{II}, \text { uidA } \\
\text { uidA } \\
n p t \mathrm{II}, \text { uidA } \\
n p t \mathrm{II}, \text { uidA } \\
n p t \mathrm{II}, g f p\end{array}$ & $\begin{array}{l}\text { BOMMINENI et al., 1994; } \\
\text { CHAREST et al., 1993; } \\
\text { DUCHESNE and } \\
\text { CHAREST, 1991; } \\
\text { DUCHESNE and } \\
\text { CHAREST, 1992; } \\
\text { HAY et al., 1994; } \\
\text { TIAN and SEGUIN, 2004; } \\
\text { TIAN et al., 1999 }\end{array}$ \\
\hline Picea mariana & E & cat & TAUTORUS et al., 1989 \\
\hline $\begin{array}{l}\text { Pseudotsuga } \\
\text { menziessii }\end{array}$ & Ar & T-DNA & MORRIS et al., 1989 \\
\hline $\begin{array}{l}\text { Pseudotsuga } \\
\text { menziessii }\end{array}$ & At & $\begin{array}{l}\text { aphII } \\
\text { nptII, Ti T-DNA, luc } \\
\text { Ti T-DNA }\end{array}$ & $\begin{array}{l}\text { DANDEKAR et al., 1987; } \\
\text { ELLIS et al., 1989; } \\
\text { MORRIS et al., } 1989\end{array}$ \\
\hline $\begin{array}{l}\text { Pseudotsuga } \\
\text { menziessii }\end{array}$ & B & uidA & GOLDFARB et al., 1991 \\
\hline Taxus brevifolia & At & Ti T-DNA & HAN et al., 1994 \\
\hline Taxus baccata & At & Ti T-DNA & HAN et al., 1994 \\
\hline Tsuga heterophylla & $\mathrm{Ar}$ & T-DNA & MORRIS et al., 1989 \\
\hline Tsuga heterophylla & At & Ti T-DNA & MORRIS et al., 1989 \\
\hline Tsuga heterophylla & B & nptII, uidA & HAY et al., 1994 \\
\hline
\end{tabular}

The application of genetic engineering technology to conifers has lagged behind many other plant species including non-coniferous trees (CONFALONIERI et al., 2003). This has been due to additional challenges specific to conifers, including long breeding cycles and rotation times, difficulties with tissue culture, and often a lack of efficient plant regeneration, and genetic transformation protocols.

The genetic improvement of conifer species to increase productivity, improve wood quality, produce novel compounds/products, and to reduce environmental impacts of forestry and forestry-based production of goods, is highly desirable in an environmental and economic context and on a worldwide scale. It has also been argued that it is imperative to achieve significant gains using plantation forestry, to provide alternatives to harvesting old-growth forests (FENNING and Gershzenson, 2002; WALter and FenNing, 2004).

There are however, many desirable traits that are not readily available within the breeding population of conifer species of interest, e.g. accelerated flowering, or input traits such as resistance to insects, pathogens, 
environmentally adverse conditions and herbicides. Furthermore, significant improvements in wood quality traits, or applications where conifers produce novel biomaterials besides wood appear possible, however in all of these cases, the introduction and controlled expression of new genes from other organisms is required.

Biolistic $^{\circledR}$ and Agrobacterium-mediated gene transfer dominate conifer genetic transformation (Table 1 and 2). Other techniques, such as electroporation and PEGmediated transformation have been reported (BEKKAOUI et al., 1988; WILSON et al., 1989), however these techniques have not yet led to the production of transgenic conifer plants (Table 1).

Biolistic $^{\circledR}$ gene transfer or gene gun-assisted transformation involves shooting small ( $1 \mu \mathrm{m}$ diameter $)$ gold or tungsten particles coated with DNA into cells (KLEIN et al., 1987). Under ideal conditions, DNA may integrate into the genome of the target cell, which subsequently needs to be regenerated to form a genetically modified tree.

Alternatively, Agrobacterium-mediated gene transfer makes use of the soil bacterium's ability to transfer part of its own DNA (the transferred DNA or T-DNA) into plant cells of different species. This DNA can be integrated into the plant's genome and in nature it causes the production of tumours and associated changes in plant metabolism (BINNS, 2002; HoEKEMA et al., 1983; LACROIX et al., 2006). In plant biotechnology, the T-DNA is replaced by a gene construct of interest flanked by the essential T-DNA border sequences that can then be transferred into plant cells by Agrobacterium species.

A range of transformation methods have been used successfully to genetically engineer conifer tissue (Table 1) and more recently, to produce transgenic plants (Table 2). SEDEROFF et al. (1986) reported the first successful Agrobacterium-mediated conifer transformation with Pinus taeda. BeKKaOUI et al. (1988) and GuPTA et al. (1988) both reported conifer transformation using electroporation in 1988 using Picea glauca and P. menziessii respectively. However, plant regeneration was not achieved in any of these early efforts. Several years later, Duchesne and CHARest (1991), Ellis et al. (1991), GOLDFARB et al. (1991) and STOMP et al. (1991) transformed Picea mariana and Larix x eurolepis, Picea glauca, Pseudotsuga menziessii and P. taeda respectively, using Biolistics ${ }^{\circledR}$. Again, transgenic plants were not produced from these transformation experiments (Table 1).

\section{Regeneration of genetically engineered conifer trees}

HUANG (1991) reported the production of conifer plants using Agrobacterium-infection. In this experiment, Larix decidua hypocotyl segments were treated with Agrobacterium containing a wild type root inducing (Ri) plasmid. This was shown to be incorporated into the genome using Southern hybridisation.

The first report on the production of transgenic conifer plants was published by ELLIs et al. (1993) using Biolistics $^{\circledR}$. They bombarded embryogenic cell lines of $P$. glauca, with a plasmid containing nptII, uidA and cry $1 \mathrm{~A}$. Conformation of transformation was shown histochemically, using PCR and Southern hybridisation, and the functionality of the insect resistance gene, cry $1 \mathrm{~A}$ was demonstrated in feeding studies with Chorisoneura fumiferana, a lepidopteran insect.

The first transgenic pine trees were reported in 1998 (Pinus radiata, WALTER et al., 1998). Embryogenic cell lines of $P$. radiata were biolistically transformed and plants containing and expressing the $n p t \mathrm{II}$ and uidA genes were regenerated. Histochemical and flurometric analysis, along with PCR, Southern and Northern hybridisation were used to confirm successful transformation.

More recently, several other commercially important conifer species have been successfully transformed and plants produced. Transgenic Picea abies plants were reported by WALTER et al. (1999), who applied a Biolistic $^{\circledR}$ technique to embryogenic cell lines. TANG et al. (2001) infected Pinus taeda embryos with A. tumefaciens and inserted $h p t$, uidA and aphII. The only report on transgenic Abies nordmanniana plants (FInd et al., 2005) used Biolistic ${ }^{\circledR}$ transformation. The inserted genes were analysed histochemically, flurometrically, with PCR, Southern hybridisation and DNA/T-DNA junction analysis.

It is important to note that most published reports on conifer transformation are using reporter and selection genes, which are necessary to select for and monitor successful genetic transformation. The more recent application of commercially important genes, such as insect and herbicide resistance and lignin biosynthesis genes, demonstrate that conifer biotechnology is now entering a phase of potential commercial deployment in plantation forestry (BISHOP HURLEY et al., 2001; CHARITY et al., 2005; GRACE et al., 2005; TANG et al., 2003; WAGNER et al., 2005).

Field trials all over the world are assessing the operational and environmental safety of transgenic conifers and mechanisms to prevent unintended gene flow from conifers are also being studied in field tests (FAO, 2004).

Although genetic transformation of conifers in the laboratory is well proven, the commercial deployment of genetically modified conifers is still in its infancy. Common limitations are the cost efficiency of the transformation technology and their application to transforming most, if not all, genotypes. Recently, a Biolistic ${ }^{\circledR}$ transformation technique that increased transformation efficiency by $2-3$ orders of magnitude and also increased the number of suitable radiata pine genotypes has been developed (C. WALTER, unpublished). More research is however necessary before transgenic conifers can economically be produced for plantation forestry.

\section{The future: A vision for biotechnology-enhanced plantation forestry}

The tools of biotechnology are beginning to find applications in currently practised forest tree improvement and plantation forestry technologies. Admittedly this is still mainly related to experimental stages and laboratory use, with the exception of some commercial planta- 
tions of genetically modified poplar in China (LIDA et al., 2003). However, many field tests of genetically modified plantation forest trees are underway (FAO, 2004) and it can be expected that more commercial plantations will appear in the near future (PILATE et al., 2002; SEDJO, 2001). So the question needs to be asked: what will be the future of plantation forestry, and what new and valuable traits do we need to identify now?

Recently, we have witnessed a significant change in forest ownership from primary industry ownership to ownership by investment funds and private investors.
This comes with a demand on forests to achieve higher rates of return. Investors also identify the need for higher-quality wood to be produced in much shorter forest crop rotations than today, on marginal land and protected against disease and predation. It is expected that these goals will be achieved at decreased growing costs, and with much more efficient use of land (CARSON et al., 2004; SEDJO, 2001).

Most importantly and driven by a growing world population, the demand for wood and wood products will increase significantly, in particular in developing coun-

Table 2. - Research published on transformation of conifers with transgenic plants produced. Abbreviations; aph: gene for amino glycoside phosphotransferase; Ar: Agrobacterium rhizogenes; aroA gene for glyphosate tolerance; At: Agrobacterium tumefaciens; B: Biolistic ${ }^{\circledR}$; bar: gene for phosphinothrycin resistance; cry1Ac gene for cry1A endotoxin or the Bacillus thuringensis endotoxin; cad: gene for cinnamyl alcohol dehydrogenase; cat: gene for chloramphenicol acetyltransferase; $g f p$ : gene for green fluorescent protein; luc: gene for luciferase; nptII: gene for neomycin phosphotransferase; sar gene for scaffold attachment region; Ti: tumor inducing; uidA: gene for $\beta$-glucuronidase.

\begin{tabular}{|c|c|c|c|}
\hline Species & $\begin{array}{l}\text { Transformation } \\
\text { method }\end{array}$ & $\begin{array}{l}\text { Transferred } \\
\text { gene/s }\end{array}$ & Reference \\
\hline \begin{tabular}{|l|} 
Abies \\
nordmanniana
\end{tabular} & B & nptII, uidA & FIND et al., 2005 \\
\hline Larix decidua & Ar & $\begin{array}{l}\text { nptII, cry } 1 \mathrm{Ac} \text { or } \\
\text { aroA } \\
\text { nptII, cry } 1 \mathrm{Ac} \text { or } \\
\text { aroA }\end{array}$ & $\begin{array}{l}\text { KARNOSKY, 1994; } \\
\text { SHIN et al., } 1994\end{array}$ \\
\hline Larix decidua & At & $\begin{array}{l}\text { Root inducing } \\
\text { plasmid }\end{array}$ & HUANG, 1991 \\
\hline $\begin{array}{l}\text { Larix kaempferi } x \mathrm{~L} \\
\text { decidua }\end{array}$ & At & $n p t \mathrm{II}$ & LEVÉE et al., 1997 \\
\hline Larix laricina & B & nptII, uidA & KLIMASZEWSKA et al., 1997 \\
\hline$P$. pinaster & At & aph, uidA & TRONTIN et al., 2002 \\
\hline P. pinaster & B & aph, uidA & TRONTIN et al., 2002 \\
\hline$P$. radiata & At & $\begin{array}{l}n p t \mathrm{II}, \text { uidA, bar } \\
n p t \mathrm{II}, \text { uidA }\end{array}$ & $\begin{array}{l}\text { CHARITY et al., 2005, } \\
\text { GRANT et al., } 2004\end{array}$ \\
\hline P. radiata & B & $\begin{array}{l}\text { nptII, uidA, bar, } \\
\text { germin } \\
\text { nptII, cry } 1 \mathrm{Ac} \\
\text { uidA, cad } \\
\text { nptII, uidA }\end{array}$ & $\begin{array}{l}\text { BISHOP-HURLEY et al., 2001; } \\
\text { GRACE et al., 2005; } \\
\text { WAGNER et al., 2005; } \\
\text { WALTER et al., } 1998\end{array}$ \\
\hline P. roxbughii & $B$ & uidA, bar & PARASHARAMI et al., 2006 \\
\hline P. strobus & At & $\begin{array}{l}\text { nptII, uidA or } g f p, \\
\text { uidA, sar }\end{array}$ & LEVÉE et al., 1999 \\
\hline P. taeda & At & $\begin{array}{l}\text { hptII, uidA } \\
\text { aphII, uidA, }\end{array}$ & $\begin{array}{l}\text { TANG, 2003; } \\
\text { TANG et al., } 2001\end{array}$ \\
\hline P. taeda & B & $\begin{array}{l}\text { nptII, cry } 1 \mathrm{Ac} \\
n p t \mathrm{II}, \text { cry } 1 \mathrm{Ac}\end{array}$ & $\begin{array}{l}\text { TANG and SAMUELS, 2002; } \\
\text { TANG and TIAN, } 2003\end{array}$ \\
\hline P. virginiana & At & $g f p 5$ & TANG et al., 2005 \\
\hline P. sylvestris & B & nptII, uidA & ARONEN et al., 2003 \\
\hline Picea abies & At & $\begin{array}{l}\text { nptII, uidA } \\
\text { nptII or aph }\end{array}$ & $\begin{array}{l}\text { KLIMASZEWSKA et al., 2001; } \\
\text { KLIMASZEWSKA et al., } 2005\end{array}$ \\
\hline Picea abies & B & $\begin{array}{l}\text { nptII, uidA, bar, } \\
\text { germin } \\
\text { bar } \\
\text { bar, uidA } \\
\text { nptII, uidA }\end{array}$ & $\begin{array}{l}\text { BISHOP-HURLEY et al., 2001; } \\
\text { BRUKHIN et al., 2000; } \\
\text { CLAPHAM et al., 2000; } \\
\text { WALTER et al., } 1999\end{array}$ \\
\hline Picea glauca & At & $\begin{array}{l}n p t \mathrm{II}, \text { uidA } \\
n p t \mathrm{II} \text { or } a p h \\
n p t \mathrm{II}, \text { uidA }\end{array}$ & $\begin{array}{l}\text { KLIMASZEWSKA et al., 2001; } \\
\text { KLIMASZEWSKA et al., 2005; } \\
\text { LE et al., } 2001\end{array}$ \\
\hline Picea glauca & B & nptII, uidA, cry $1 \mathrm{Ac}$ & ELLIS et al., 1993 \\
\hline Picea mariana & At & $\begin{array}{l}n p t \mathrm{II}, \text { uidA } \\
n p t \mathrm{II} \text { or } a p h\end{array}$ & $\begin{array}{l}\text { KLIMASZEWSKA et al., 2001; } \\
\text { KLIMASZEWSKA et al., 2005, }\end{array}$ \\
\hline Picea mariana & B & $\begin{array}{l}\text { nptII, uidA } \\
\text { aph, uidA }\end{array}$ & $\begin{array}{l}\text { CHAREST et al., 1996; } \\
\text { TIAN et al., } 2000\end{array}$ \\
\hline $\begin{array}{l}\text { Populus } \\
\text { tremuloides }\end{array}$ & $A r$ & $\begin{array}{l}\text { nptII, cry } 1 \mathrm{Ac} \text { or } \\
\text { aroA }\end{array}$ & KARNOSKY, 1994 \\
\hline
\end{tabular}


tries (Brown, 2000; Fenning and Gershzenson, 2002). Land used for growing forests will have to compete for other uses such as growing food and feed, and increasingly plant-derived biomaterials (FAO, 2003). The public will demand environmentally sustainable wood production and this will ultimately lead to strong support for the superior production rates of plantation forestry to be further enhanced using modern biotechnologies. At the same time, there will be an increasing demand that natural forests will be left alone (VICTOR, 2000). The insight that unsustainable harvesting practices must not be continued, will lead to even stronger support for environmentally acceptable applications of biotechnology (GARTLAND et al., 2002). Besides producing timber trees will increasingly be required to act as 'factories' for new biomaterials and new types of fibres. This is particularly significant where biotechnology and nanotechnology are combined in production processes (ANON, 2004).

This vision however, provides a number of significant challenges for foresters and biotechnologists. These challenges are both technological and social, and we will need to be increasingly aware of the global context of biomaterials. Successful implementation of new biotechnologies in this field will also require a more balanced and fact-based public discussion of risk, in particular in the context of the benefits achievable.

This leads us to offer a few thoughts on risk and risk perception. More detailed discussions of the perceived operational and environmental risks potentially associated with tree biotechnology can be found in (BURDON and Walter, 2004; Cauley, 2002; Fenning and Gershzenson, 2002; LANG, 2004; OwUsu, 1999; Walter and FenNing, 2004).

\section{Biotechnology and risk: Are modern societies risk averse?}

It is important to note that while modern technologies including biotechnologies are taken up by most societies at unprecedented speed, there is often also a certain amount of resistance (e.g. DALE, 1999 and 2002; LANG, 2004). Some Non-Governmental Organisations (NGO's) have received praise but also strong criticism for their activities in this field (KaIser, 2001; PEARCE, 2001; Strauss, 2001; Walter, 2004; Walter and Fenning, 2004), which some regard as a crime against humanity (MOORE, 2004).

It has been argued that the current risk-averse position of parts of our society in general, is based on a deeply held, pessimistic view of what science can contribute to human welfare, and a resulting inability to balance risk and benefit (TAVERNE, 2005). In the debate on genetic engineering, concerns are sometimes expressed that something unexpected will happen with genetically modified plants, and this is seen as unacceptable risk per se. However, this unexpected effect is usually not defined, nor is its occurrence substantiated in any way. It is argued instead, that because of the unexpected element, the risk is too high and genetic modification should not proceed (LANG, 2004). The precautionary principle is frequently used to support this argument. It can, however, be argued that, in human society, any activity is associated with some degree of risk and a risk-free environment is impossible to achieve (TAVERNE, 2005). Humans make many subconscious or conscious decisions whether or not to accept a specific risk, in order to gain some benefit. In the discussions surrounding genetic engineering, it often appears as if the risk associated with this new technology is being compared to a situation where risk does not exist. Consequently, the taking of any risk, regardless of benefit, is seen as an unacceptable option, and so it is asserted that all use of genetic modification should be terminated. However, logic demands that the risk associated with a specific outcome (the environmentally sustainable production of wood, for example) must be compared to how else this particular outcome may be achieved, rather than "doing nothing". Interpreting the precautionary principle in the way described also amounts to a decision, with its own consequences, intended or otherwise (ConNer et al., 2003). Those consequences could easily be worse than the risk related to the dismissed technology.

\section{Risk of using GE trees in plantation forestry}

When focussing on the risk of deployment of genetically modified trees, we should first note that widely accepted and practised technologies, such as conventional tree breeding, are also not risk-free (e.g. KuBE and CARSON, 2004). Traditional breeding is an intrinsically imprecise process since the new variations, created through recombination or mutations, are usually not well characterised at the genetic level. Breeders use selection in an attempt to remove much unwanted variation, but it is still possible for mistakes to occur, and many changes certainly go unnoticed. This appears to be much less controllable than genetic engineering, where only one or a few characterised genes may be either added, or their expression altered (CONNER et al., 2003). However, the risk of using genetically modified trees should be discussed in the context of operational risk and environmental risk. We define operational (or technical) risk as related to the performance of a plantation, and specifically whether a genetic modification will express itself as predicted, over the rotation time. Conversely, environmental risk refers to effects of a plantation on the surrounding ecosystem. Both types of risk need careful consideration and research to better understand the magnitude and develop mitigation strategies.

Finally, we are not intending to argue that all modern biotechnology and in particular genetic engineering, is free of any risk. It is however instructive to study the risks associated with the intensive use of this technology in agriculture over the last 10 years, with no demonstrated negative impact on the environment or human health, as compared to already accepted practise. The public and political discussion around genetic engineering in forestry should be based on the facts rather than emotional arguments, and decisions should be made after thorough case-by-case analysis of both the potential risks and benefits of a new improved tree. We must accept the evidence indicating that wood demand will continue to increase in future. We must consequently find technologies to satisfy this demand in an environ- 
mentally sustainable manner, and most importantly, leaving native forests alone. Forest biotechnology can make a significant contribution to this goal.

\section{References}

ANON (2004): Nanotechnology for the forest products industry - Vision and technology roadmap. Nanotechnology for the forest products industry workshop, Lansdowne, Virginia. Download at: www.fpl.fs.fed.us/highlighted-research/nanotechnology/forest-products-nanotechnology.pdf.

Aronen, T., A. Hohtola, H. Laukkanen and H. HäGGman (1995): Seasonal changes in the transient expression of a 35S CaMV-GUS gene construct introduced into Scots pine buds. Tree Physiol. 15: 65-70.

ARONEN, T. S., T. O. NikKANEN and H. M. HÄGGMAN (1998): Compatibility of different pollination techniques with microprojectile bombardment of Norway spruce and Scots pine pollen. Can. J. For. Res. 28: 79-86.

Aronen, T. S., T. O. NikKanEN and H. M. HÄGGMAN (2003): The production of transgenic Scots pine (Pinus sylvestris L.) via the application of transformed pollen in controlled crossings. Transgenic Res. 12: 375-378.

Bekkaoui, F., M. Pilon, D. S. S. Raju, W. L. Crosby and D. I. Dunstan (1988): Transient gene expression in electroporated Picea glauca protoplasts. Plant Cell Rep. 7: 481-484.

Binns, A. N. (2002): T-DNA of Agrobacterium: 25 years and counting. Trends in Plant Sci. 7 (5): 231-233.

Bishop-Hurley, S. L., R. J. Zabkievicz, L. Grace, R. C. Gardner, A. Wagner and C. WAlter (2001): Conifer genetic engineering: Transgenic Pinus radiata (D Don) and Picea abies (Karst) plants are resistant to the herbicide Buster. Plant Cell Rep. 20: 235-243.

Bommineni, V. R., R. S. S. Datla and E. W. T. Tsang (1994): Expression of gus in somatic embryo cultures of black spruce after microprojectile bombardment. J. Exp. Bot. 45: 491-495.

BRown, C. (2002): The global outlook for future wood supply from forest plantations. FAO working paper No: GFPOS/WP/03. Download at: (http://www.fao.org/ forestry).

Brukhin, V., D. Clapham, M. Elfstrand and S. von ARNOLD (2000): Basta tolerance as a selectable and screening marker for transgenic plants of Norway spruce. Plant Cell Rep. 19: 899-903.

BURDON, R. D. and C. WALter (2004): Exotic pines and eucalypts: Perspectives on risks of transgenic plantations, pp 52-75 in The bioengineered forest: Challenges for science and society, edited by S. H. STRAuss and H. D. BRAdshaW, RFF (Resources for the Future) Press, Washington, DC, USA.

CARson, M., C. Walter and S. CARson (2004): The future of forest biotechnology. Proceedings from the Workshop Biotechnolegia Forestal. Global Biotechnology Forum, Chile. Institute of Forest Biotechnology, Raleigh, NC.

CAuley, H. (2001). Genetic engineering FSC says risks are still too great. J. For. 99(12): 4-7.

Campbell, M. A., C. S. Kinlaw and D. B. Neale (1992): Expression of luciferase and $\beta$-glucuronidase in Pinus radiata suspension cells using electroporation and particle bombardment. Can. J. For. Res. 22: 2014-2018.

Cardoza, V. and C. N. JR. Stewart (2004): Brassica Biotechnology: Progress in cellular and molecular biology. In Vitro Cell. Dev. Biol., Plant 40: 542-551.
Cerda, F., F. Aquea, M. Gebauer, C. Medina and P. ArceJoHnson (2002): Stable transformation of Pinus radiata embryogenic tissue by Agrobacterium tumefaciens. Plant Cell Tissue Organ Cult. 70: 251-257.

Charest, P. J., N. Calero, D. Lachance, R. S. S. Datla, L. C. Duchesne and E. W. T. Tsang (1993): Microprojectile-DNA delivery in conifer species: factors affecting assessment of transient gene expression using the $\beta$-glucuronidase reporter gene. Plant Cell Rep. 12: 189-193.

Charest, P. J., Y. Devantier and D. LAChance (1996): Stable genetic transformation of Picea mariana (Black Spruce) via particle bombardment. In Vitro Cell. Dev. Biol., Plant 32: 91-99.

Charity, J. A., L. Holland, S. S. Donaldson, L. Grace and C. WALTER (2002): Agrobacterium-mediated transformation of Pinus radiata organogenic tissue using vacuum infiltration. Plant Cell Tissue Organ Cult. 70: 51-60.

Charity, J. A., L. Holland, L. J. Grace and C. Walter (2005): Consistent and stable expression of the $n p t \mathrm{II}$, uidA and bar genes in transgenic Pinus radiata after Agrobacterium tumefaciens-mediated transformation using nurse cultures. Plant Cell Rep. 23: 606-616.

Clapham, D., I. Ekberg, G. ERIKSSON, E. E. Hood and L. NORELL (1990): Within-population variation in susceptibility to Agrobacterium tumefaciens A281 in Picea abies (L.) Karst. Theor. Appl. Genet. 79: 654-656.

Clapham, D., P. Demel, M. Elfstrand, H.-U. Koop, I. SABALA and S. von ARNOLD (2000): Gene transfer by particle bombardment of embryogenic cultres of Picea abies and the production of transgenic plantlets. Scand. J. For. Res. 15: 151-160.

Confalonieri, M., A. Balestrazzi, S. Bisoffi and D. CarBONERA (2003): In vitro culture and genetic engineering of Populus spp.: synergy for forest tree improvement. Plant Cell Tissue Organ Cult. 72: 109-138.

DandeKar, A. M., P. K. GUPTA, D. J. DuRZAN and V. Knauf (1987): Transformation and foreign gene expression in micropropagated Douglas-fir (Pseudotsuga menziesii). Bio/Technology 5: 587-590.

DineR, A. M. and D. F. KARNosky (1987): Differential responses of two conifers to in vitro inoculation with Agrobacterium rhizogenes. Eur. J. Forest Pathol. 17: 211-216.

Drake, P. M. W., A. John, J. B. Power and M. R. Davey (1997): Expression of the gus A gene in embryogenic cell lines of Sitka spruce following Agrobacterium mediated transformation. J. Exp. Bot. 48: 151-155.

DuChesne, L. C. and P. J. Charest (1991): Transient expression of the $\beta$-glucuronidase gene in embryogenic callus of Picea mariana following microprojection. Plant Cell Rep. 10: 191-194.

Duchesne, L. C. and P. J. Charest (1992): Effect of promoter sequence on transient expression of the $\beta$-glucuronidase gene in embryogenic calli of Larix $\mathrm{x}$ eurolepis and Picea mariana following microprojection. Can. J. Bot. 70: 175-180.

Duchesne, L. C., A.-M. Lelu, P. von Aderkas and P. J. ChAREST (1993): Microprojectile-mediated DNA delivery in haploid and diploid embryogenic cells of Larix spp. Can. J. For. Res. 23: 312-316.

Ellis, D., D. Roberts, B. Sutton, W. Lazaroff, D. WebB and B. FlinN (1989): Transformation of white spruce and other conifer species by Agrobacterium tumefaciens. Plant Cell Rep. 8: 16-20. 
Ellis, D. D., D. McCabe, D. Russell, B. Martinell and B. H. McCown (1991): Expression of inducible angiosperm promoters in a gymnosperm, Picea glauca (white spruce). Plant Mol. Biol. 17: 19-27.

Ellis, D. D., D. E. McCabe, S. McInnis, R. RamachanDRan, D. R. Russell, K. M. Wallace, B. J. Martinell, D. R. Roberts, K. F. RAFFA and B. H. McCown (1993): Stable transformation of Picea glauca by particle acceleration. Bio/Technology 11: 84-89.

FAO (2003) The state of the world's forests 2003. FAO Rome, 2003.

FAO (2004): Preliminary review of biotechnology in forestry, including genetic modification. Forest Genetic Resources Working Paper FGR/59E. Forest Resources Development Service, Forest Resources Division. Rome Italy.

Fenning, T. M. and J. Gershenzon (2002): Where will the wood come from? Plantation forests and the role of biotechnology. Trends Biotechnol. 20: 291-296.

FERNANDO, D. D., J. N. Owens and S. MisRa (2000): Transient gene expression in pine pollen tubes following particle bombardment. Plant Cell Rep. 19: 224-228.

Find, J. I., J. A. Charity, L. J. Grace, M. M. M. H. Kristensen, P. Krogstrup and C. Walter (2005): Stable genetic transformation of embryogenic cultures of Abies nordmanniana (Nordmann fir) and regeneration of transgenic plants. In Vitro Cell. Dev. Biol., Plant 41: 725-730.

Gartland, K. M. A., R. C. Kellison and T. M. Fenning (2003): Forest biotechnology and Europe's forests for the future. Forest Biotechnology in Europe: Impending barriers, policy and implications, pp. 53-84. In: Forest Biotechnology in Europe. The Challenge, the Promise, the Future, edited by K. M. A. Gartland, R. C. KelliSON, T. M. FEnNing and S. McCorD. Institute of Forest Biotechnology, North Carolina.

Goldfarb, B., S. H. Strauss, G. T. Howe and J. B. Zaerr (1991): Transient gene expression of microprojectileintroduced DNA in Douglas-fir cotyledons. Plant Cell Rep. 10: 517-521.

Grace, L. J., J. A. Charity, B. Gresham, N. Kay and C. WALter (2005): Insect-resistant transgenic Pinus radiata. Plant Cell Rep. 24: 103-111.

GRANT, J. E., P. A. CoOPER and T. M. DALE (2004): Transgenic Pinus radiata from Agrobacterium tumefaciensmediated transformation of cotyledons. Plant Cell Rep. 22: 894-902.

Gupta, P. K., A. M. DANDEKAR and D. J. DuRZAN (1988): Somatic proembryo formation and transient expression of a Luciferase gene in Douglas fir and Loblolly pine protoplasts. Plant Sci. 58: 85-92.

Han, K-H., P. Fleming, K. Walker, M. Loper, S. W. Chilton, U. Mocek, M. P. Gordon and L. C. Fowke (1994): Genetic transformation of mature Taxus: an approach to genetically control the in vitro production of the anticancer drug, taxol. Plant Sci. 95: 187-196.

HAY, I., D. LAChance, P. vON AdERKAS and P. J. Charest (1994): Transient chimeric gene expression in pollen of five conifer species following microparticle bombardment. Can. J. For. Res. 24: 2417-2423.

HäGgman, H. M., T. S. ARonen and T. O. NikKanen (1997): Gene transfer by particle bombardment of Norway spruce and Scots pine pollen. Canadian Journal of Forest Research 27: 928-935.

HÄGGMAN, H. and T. ARONEN (1998): Transgene expression in regenerating cotyledons and embryogenic cultures of Scots pine. J. Exp. Bot. 49: 1147-1156.
Hoekema, A., P. R. Hirsch, P. J. J. HooykaAs and R. A. SCHILPEROORT (1983): A binary plant vector strategy based on separation of vir- and T-region of the Agrobacterium tumefaciens Ti-plasmid. Nature 303: 179-180.

Holland, L., J. E. Gemmell, J. A. Charity and C. Walter (1997): Foreign gene transfer into Pinus radiata cotyledons by Agrobacterium tumefaciens. New Zeal. J. For. Sci. 27: 289-304.

Huang, Y., A. M. Diner and D. F. Karnosky (1991): Agrobacterium rhizogenes-mediated genetic transformation and regeneration of a conifer: Larix decidua. In Vitro Cellular and Developmental Biology 27: 201-207.

Huang, Y., D. D. Stokke, A. M. Diner, W. M. Barnes and D. F. KARNOSKY (1993): Virulence of Agrobacterium on Larix decidua and their cellular interactions as depicted by scanning electron microscopy. J. Exp. Bot. 44: 1191-1201.

HuAnG, Y. and C. G. TAUER (1994): Integrative transformation of Pinus taeda L. and P. echinata Mill by Agrobacterium tumefaciens. For. Genet. 1: 23-31.

Humara, J. M., M. LÓPEZ and R. J. ORDÁs (1998): Modifying transient $\beta$-glucuronidase expression in pine species using introns. Plant Cell Tissue Organ Cult. 52: 183-187.

Humara, J. M., M. LóPez and R. J. ORdÁs (1999): Agrobacterium rhizogenes-mediated transformation of Pinus pinea L. cotyledons: an assessment of factors influencing the efficiency of uidA gene transfer. Plant Cell Rep. 19: $51-58$.

HumARA, J. M., M. LÓPEZ and R. J. ORDÁs (1999): Transient expression of the uidA gene in Pinus pinea cotyledons: A study of heterologous promoter sequences. Plant Cell Tissue Organ Cult. 56: 69-78.

ISAAA (2005): ISAAA Briefs No. 34: Global status of Biotech Crops.

Karnosky, D. F., D. I. Shin and V. L. ChiAng (1994): Progress in production of transgenic trees with valueadded genes: Results with Larch and Aspen, pp 157-160 in Biological Sciences Symposium, TAPPI Proceedings.

Klein, T. M., E. D. Wolf, R. Wu and J. C. SAngord (1987): High-velocity microprojectiles for delivering nucleic acids into living cells. Nature 327: 70-73.

KLIMAszewska, K., Y. DevantieR, D. Lachance, M.-A. LeLU and P. J. ChAREST (1997): Larix laricina (tamarack): somatic embryogenesis and genetic transformation. Can. J. For. Res. 27: 538-550.

Klimaszewska, K., D. Lachance, G. Pelletier, M.-A. LELU and A. SÉGUIN (2001): Regeneration of transgenic Picea glauca, P. mariana, and P. abies after cocultivation of embryogenic tissue with Agrobacterium tumefaciens. In Vitro Cellular and Developmental Biology 37(6): 748-755.

Klimaszewska, K., D. LaChance, M. Bernier-Cardou and R. G. RuthledGe (2003): Transgene integration patterns and expression levels in transgenic tissue lines of Picea mariana, P. glauca and P. abies. Plant Cell Rep. 21: 1080-1087.

Klimaszewska, K., R. G. Rutledge and A. SÉGuin (2005): Genetic transformation of conifers utilizing somatic embryogenesis. Methods Mol. Biol. 286: 151-163.

LacroiX, B., T. TzFira, A. Vainstein and V. Citovsky (2006): A case of promiscuity: Agrobacterium's endless hunt for new partners. Trends Genet. 22(1): 29-77.

Lambardi, M., D. Lachance, A. SÉguin and P. J. Charest (1998): Evaluation of microprojectile-mediated DNA delivery and reporter genes for genetic transformation 
of the Mediterranean cypress (Cupressus sempervirens L.). Plant Cell Rep. 18: 198-202.

LANG, C. (2004) Genetically modified trees - the ultimate threat to forests. World Rainforest Movement and Friends of the Earth. Download at: http://www.foei.org.

Le, V. Q., J. Belles-Isles, M. Dusabenyagasani and F. M. TREMBLAY (2001): An improved procedure for production of white spruce (Picea glauca) transgenic plants using Agrobacterium tumefaciens. J. Exp. Bot. 52: 2089-2095.

Levée, V., M.-A. Lelu, L. Jounanin, D. Cornu and G. Pilate (1997): Agrobacterium tumefaciens-mediated transformation of hybrid larch (Larix kaempferi x $L$. decidua) and transgenic plant regeneration. Plant Cell Rep. 16: 680-685.

Levée, V., E. Garin, K. Klimaszewska and A. Séguin (1999): Stable genetic transformation of white pine (Pinus strobus L.) after cocultivation of embryogenic tissues with Agrobacterium tumefaciens. Mol. Breed. 5: 429-440.

LI, Y.-H., F. M. TRemblay and A. SÉGuIN (1994): Transient transformation of pollen and embryogenic tissues of white spruce (Picea glauca (Moench.) Voss) resulting from microprojectile bombardment. Plant Cell Rep. 13: 661-665.

LidA, W., H. YIfAN and H. JiAnJun (2003): Transgenic forest trees for insect resistance, pp. 243-261. In: Molecular Genetics and Breeding of Forest Trees, edited by S. Kumar and M. Fladung, The Haworth Press, Binghamton, USA.

Loopstra, C. A., A.-M. Stomp and R. R. Sederoff (1990): Agrobacterium-mediated DNA transfer in sugar pine. Plant Mol. Biol. 15: 1-9.

Magnussen, D., D. Clapham, R. GrönRoos and S. von ARNOLD (1994): Induction of Hairy and Normal Roots on Picea abies, Pinus sylvestris and Pinus cortorta by Agrobacterium rhizogenes. Scandanavian Journal of Forest Research 9: 46-51.

Martinussen, I., O. Junttila and D. Twell (1994): Optimization of transient gene expression in pollen of Norway spruce (Picea abies) by particle acceleration. Physiol. Plantarum 92: 412-416.

MAZUR, B. J. and S. C. FALCO (1989): The development of herbicide resistant crops. Annu. Rev. Plant Physiol. Plant Mol. Biol. 40: 441-470.

MinaJlevic, S., S. Stipkovic and S. Jelaska (1996): Increase of root induction in Pinus nigra explants using Agrobacteria. Plant Cell Rep. 15: 610-614.

MOHRI, T., T. IGASAKI, T. SATO and K. SHINOHARA (2000): Expression of genes for $\beta$-glucuronidase and luciferase in three species of Japanese conifer (Pinus thunbergii, P. densiflora and Cryptomeria japonica) after transfer of DNA by microprojectile bombardment. Plant Biotechnol. 17: 49-54.

Moore, P. (2004): Battle for biotech progress. The American Enterprise Online, available online: http://www. taemag.com/issues/articleid.17889/article_detail.asp

MorRIS, J. W., L. A. CASTLE and R. O. MorRIS (1989): Efficacy of different Agrobacterium tumefaciens strains in transformation of pinaceous gymnosperms. Physiol. Mol. Plant Path. 34: 451-461.

Möller, R., A. G. MCDonald, C. Walter and P. J. Harris (2003): Cell differentiation, secondary cell-wall formation and transformation of callus tissue of Pinus radiata D. Don. Planta 217: 736-747.

Nigro, S. A., N. P. MAKUnGa, N. B. Jones and J. VAN STADEN (2004): A Biolistic approach towards producing transgenic Pinus patula embryonal suspensor masses. Plant Growth Regul. 44: $187-197$.
OwUsu, R. A. (1999). GM technology in the forest sector. A scoping study for the WWF. WWF-UK.

Parasharami, V. A., V. B. Naik, S. von Arnold, R. S. NADGAUdA and D. H. Clapham (2006): Stable transformation of mature zygotic embryos and regeneration of transgenic plants of chir pine (Pinus roxbughii Sarg.). Plant Cell Rep. 24: 708-714.

Rey, M., M. V. GonzÁlez, R. J. Ordás, R. TAvazza and G. ANCORA (1996): Factors affecting transient gene expression in cultured radiata pine cotyledons following bombardment. Physiol. Plantarum 96: 630-636.

Robertison, D., A. K. Weissinger, R. Ackley, S. Glover and R. R. SEDEROFF (1992): Genetic transformation of Norway spruce (Picea abies (L.) Karst) using somatic embryo explants by microprojectile bombardment. Plant Mol. Biol. 19: 925-935.

SalaJ, T., J. Moravcikova, L. Grec-Niquet and J. SalaJ (2005): Stable transformation of embryogenic tissues of Pinus nigra Arn. using a biolistic method. Biotechnol. Lett. 27: 899-903.

SAlajova, T., J. SALAJ and A. KoRmutak (1999): Initiation of embryogenic tissues and plantlet regeneration from somatic embryos of Pinus nigra Arn. Plant Sci. 145: $33-40$.

Sautter, C., S. Poletti, P. Zhang and W. Gruissem (2006): Biofortification of essential nutritional compounds and trace elements in rice and cassava. Symposium on 'Enhancing the nutritional value of plant foods' 65: $153-159$.

Sederoff, R., A.-M. Stomp, W. S. Chilton and L. W. Moore (1986): Gene transfer into loblolly pine by Agrobacterium tumefaciens. Bio/Technology 4: 647-649.

SEDJO, R. (2001) Biotechnology's potential contribution to global wood supply and forest conservation. Resources for the future, Washington D.C.

SEDJo, R. (2004) Potential for biotechnology applications in plantation forestry, pp. 3-24. In: Plantation Forest Biotechnology for the $21^{\text {st }}$ Century, edited by C. WALter and M. CARSON, Kerala, India.

Sharma, H. C., K. K. Sharma and J. H. Crouch (2004): Genetic transformation of crops for insect resistance: Potential and limitations. Crit. Rev. Plant Sci. 23: 47-72.

Shin, D. I., G. K. Podila, Y. Huang and D. F. KaRnosky (1994): Transgenic larch expressing genes for herbicide and insect resistance. Can. J. For. Res. 24: 2059-2067.

Stomp, A. M., A. Weissinger and R. R. SEDeroff (1991): Transient expression from micro-projectile-mediated DNA transfer in Pinus taeda. Plant Cell Rep. 10: 187-190.

Strauss, S. H., P. Coventry, M. M. Campbell, S. N. Pryor and J. BuRLEY (2001): Certification of genetically modified forest plantations. Int. For. Rev. 3: 87-104.

TANG, W., R. SEDEROFF and R. Whetten (2001): Regeneration of transgenic loblolly pine (Pinus taeda L.) from zygotic embryos transformed with Agrobacterium tumefaciens. Planta 213: 981-989.

TANG, W. (2001): Agrobacterium-mediated transformation and assessment of factors influencing transgene expression in loblolly pine (Pinus taeda L.). Cell Res. 11: 237-243.

TANG, W. and V. SAMUELS (2002): Genetic transformation of Pinus taeda by particle bombardment. Journal of

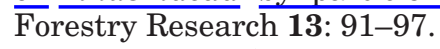

TANG, W. (2003): Additional virulence genes and sonication enhance Agrobacterium tumefaciens-mediated loblolly pine transformation. Plant Cell Rep. 21: $555-562$. 
TANG, W. and Y. TIAN (2003): Transgenic loblolly pine (Pinus taeda L.) plants expressing a modified deltaendotoxin gene from Bacillus thuringiensis with enhanced resistance to Dendrolimus punctatus Walker and Crypyothelea formosicola Staud. J. Exp. Bot. 54: 835-844.

TANG, W., R. J. Newton and T. M. Charles (2005): High efficiency inducible gene expression systems based on activation of a chimeric transcription factor in transgenic pine. Plant Cell Rep. 24: 619-628.

Tautorus, T. E., F. Bekkaoui, M. Pilon, R. S. S. Datla, W. L. Crosby, L. C. Fowke and D. I. Dunstan (1989): Factors affecting transient gene expression in electroporated black spruce (Picea mariana) and jack pine (Pinus banksiana) protoplasts. Theor. Appl. Genet. 78: 531-536.

Tian, L., V. Levée, R. Mentag, P. J. Charest and A. SEGUIN (1999): Green fluorescent protein as a tool for monitoring transgene expression in forest tree species. Tree Physiol. 19: 541-546.

Tian, L.-N., P. J. Charest, A. Seguin and R. G. Rutledge (2000): Hygromycin resistance is an effective selectable marker for biolistic transformation of black spruce (Picea mariana). Plant Cell Rep. 19: 358-362.

TIAN, L. and A. SEGUIN (2004): Microprojectile particle effect on stable transformation of black spruce via bombardment. Plant Mol. Biol. Rep. 22: 199a-199f.

Trontin, J.-F., L. Harvengt, E. Garin, M. Lopez-Bernaza, L. Arancia, J. Hoebeke, F. Canlet and M. PÂques (2002): Towards genetic engineering of maritime pine (Pinus pinaster Ait.). Ann. For. Sci. 59: 687-697.

TzFira, T., O. Yarnitzky, A. Vainstein and A. Altman (1996): Agrobacterium rhizogenes-mediated DNA transfer in Pinus halepensis Mill. Plant Cell Rep. 16: 26-31.

VICTOR, D. G. (2000) The great restoration: The potentials for forest protection to 2050 . The great restoration project: http://greatrestoration.rockefeller.edu/

Wagner, A., J. Moody, L. J. Grace and C. Walter (1997): Transformation of Pinus radiata based on selection with Hygromycin B. New Zeal. J. For. Sci. 27: 280-288.

Wagner, A., L. Phillips, R. D. Narayan, J. M. Moody and B. GEDDEs (2005): Gene silencing studies in the gymnosperm species Pinus radiata. Plant Cell Rep. 24: 95-102.

Walter, C., D. R. Smith, M. B. Connett, L. Grace and D. W. R. White (1994): A biolistic approach for the transfer and expression of a gus A reporter gene in embryogenic cultures of Pinus radiata. Plant Cell Rep. 14: 69-74.

Walter, C., S. D. Carson, M. I. Menzies, T. Richardson and M. CARSON (1998): Review: Application of biotechnology to forestry - Molecular biology of conifers. World J. Microbiol. Biotechnol. 14: 321-330.

Walter, C., L. J. Grace, A. Wagner, A. R. Walden, D. W. R. White, S. S. Donaldson, H. Hinton, R. C. GARDNER and D. R. SMith (1998b): Stable transformation and regeneration of transgenic plants of Pinus radiata D. Don. Plant Cell Rep. 17: 460-468.

Walter, C., L. J. Grace, S. S. Donaldson, J. Moody, J. E. Gemmell, S. van der MaAs, H. KvaAlen and A. LÖNNEBORG (1999): An efficient biolistic transformation protocol for Picea abies (L) Karst embryogenic tissue and regeneration of transgenic plants. Can. J. For. Res. 29: 1539-1546.

WALTER, C. (2004): Genetic engineering in conifer forestry: Technical and social considerations. In Vitro Cellular and Developmental Bioliology-Plant 40: 434-441.

Walter, C. and T. FenNing (2004): Deployment of genetically-engineered trees in plantation forestry - An issue of concern? The science and politics of genetically modified tree plantations, pp. 423-446. In: Plantation forest biotechnology for the $21^{\text {st }}$ century, edited by, C. WALTER and M. CARSON, Kerala, India.

Wang, W., B. Vinocur and A. Altman (2003): Plant responses to drought, salinity and extreme temperatures: towards genetic engineering for stress tolerance. Planta 218: 1-14.

Wenck, A. R., M. Quinn, R. W. Whetten, G. Pullmann and R. SEDEROFF (1999): High-efficiency Agrobacteriummediated transformation of Norway spruce (Picea abies) and loblolly pine (Pinus taeda). Plant Mol. Biol. 39: 407-416.

Wilson, S. M., T. A. Thorpe, and M. M. Moloney (1989): PEG-mediated expression of GUS and CAT genes in protoplasts from embryogenic suspension cultures of Picea glauca. Plant Cell Rep. 7: 704-707.

Yibrah, H. S., R. Gronroos, A. Lindroth, H. Franzen, D. Clapham and S. vON ARNOLD (1996): Agrobacterium rhizogenes mediated induction of adventitious rooting from Pinus contorta hypocotyls and the effect of 5-azacytidine on transgene activity. Transgenic Res. 5: 75-85. 